\title{
Ionizing Radiation and Lucanthone Enhance the IgG Content of Burkitt's Lymphoma Cells
}

\section{Robert Bases* and Rukmani Lekhraj}

Department of Neurosurgery, Albert Einstein College of Medicine, Montefiore Medical Center, NY 10467, USA

\begin{abstract}
Ionizing radiation or lucanthone treatment of CRL-1647, Burkitt's lymphoma cells, increased their content of IgG three fold. Radiation induced increases in IgG cell content relative to IgM persisted for several cell generations. IgM remained the predominant immunoglobulin after either treatment. Elevated AID, activation induced cytidine deaminase, was not found after $5 \mathrm{~Gy}$.
\end{abstract}

However, $8 \mu \mathrm{M}$ lucanthone for $48 \mathrm{~h}$ increased cellular AID cell content three fold and, as previous results showed progeny of lucanthone survivors exhibited increased levels of AID many generations later.

Keywords: Lucanthone; Ionizing radiation; Class switch recombination (CSR); Activation induced deoxycytidine deaminase (AID)

\section{Introduction}

Lucanthone, a thiaxanthenone, once widely used to treat schistosomiasis, induced 3.6 fold increases in immune globulin G (IgG) relative to immune globulin M (IgM) in CRL-1647 Burkitt's lymphoma cells [1]. This increase persisted for many generations and was accompanied by 7 fold increases in cellular activation induced cytidine deaminase (AID) [1]. AID is a key factor in Ig class switching from IgM to IgG.

Here we examined the effects of ionizing radiation on the ratio of $\mathrm{IgG} /(\mathrm{IgG}+\mathrm{IgM})$ (Figure 1$)$ and the content of AID in CRL-1647 cells. Lucanthone increased both by $48 \mathrm{~h}$ (Figures 1 and 2).

The novel results with ionizing radiation described later raise general questions about the mechanisms responsible for changes in $\mathrm{IgG} /(\operatorname{IgG}+\operatorname{IgM})$. AID seems not alone in altering it. While class switch recombination by AID is being very actively pursued, other mechanisms, induced by clinically available tools, deserve attention.

\section{Materials and Methods}

\section{Cells}

CRL-1647 Burkitt human lymphoma cells were purchased from American Type Culture Collection (ATCC), Manassas, VA 20108. They were grown in suspension at $37^{\circ} \mathrm{C}$ in Roswell Park Memorial Institute 1640 medium with $10 \%$ fetal bovine serum in $8 \% \mathrm{CO}_{2}$ in a humidified atmosphere. The cell culture doubling time was 24 hours. Media and sera were from ATCC.

\section{Cell lysates}

Cells were sedimented from phosphate buffered saline without $\mathrm{Ca}^{++}$ or $\mathrm{Mg}^{++}$, resuspended in lysis buffer with $10 \mu \mathrm{M}$ Aprotinin and sonicated with 20 one-second strokes, leaving 1\%-2\% unbroken cells. Lysates of $10^{7}$ to $10^{8}$ cells that were clarified by centrifugation at $15,500 \mathrm{~g}$ for $12 \mathrm{~min}$ contained approximately $1 \mu \mathrm{g} / \mu \mathrm{l}$ of protein.

\section{Western blots}

For most experiments, $7 \mathrm{~cm}$ minigels, purchased from BioRad Laboratories, Los Angeles, CA were used. Buffer without SDS or methanol, containing $25 \mathrm{mM}$ Tris, $\mathrm{pH} 8.3$ and $192 \mathrm{mM}$ glycine were

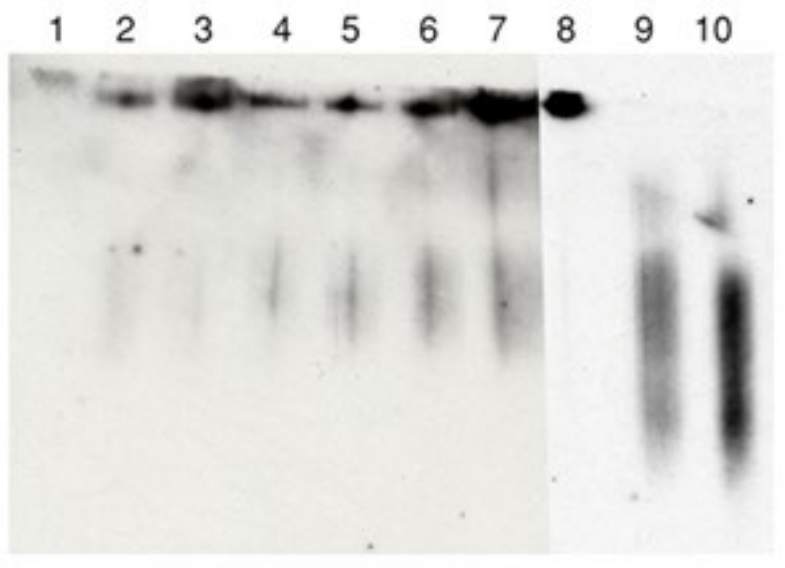

Figure 1: Radiation enhanced ratio of $\operatorname{lgG} /(\operatorname{lgG}+\lg M)$ in Burkitt's lympho cells CRL-1647. Lane 1: No cell lysate. Lanes 2 and 3: Lysates from $5.3 \times 105$ untreated cells; ratios $0.13,0.10$. Lanes 4 and 5 : Lysates from $7.5 \times 105$ cells $22 \mathrm{~h}$ after $10 \mathrm{~Gy}$; ratios $0.35,0.38$. Lanes 6 and 7 : Lysates from $6.0 \times 105$ cells growing 4 days after $5 \mathrm{~Gy}$, ratios $0.38,0.38$. Lane 8 : IgM $0.46 \mu \mathrm{g}$. Lane 9 : IgG 10-3 $\mu \mathrm{g}$. Lane 10: IgG 10-2 $\mu \mathrm{g}$. Lanes 1-7: 20 min exposure. Lanes 8, 9, 10: 1 min exposure. Lysates from $5.3 \times 105$ untreated CRL-1647 cells released 10-5 $\mu \mathrm{g}$ of $\mathrm{lgG}$ and $0.12 \mu \mathrm{g}$ of $\mathrm{IgM}$ into the gel. The ratios $\lg \mathrm{g} /(\mathrm{lgM}+\lg \mathrm{g})$ obtained from untreated cells compared with those of radiation survivors were different at $p \leq 0.00006$.

used for gel electrophoresis and Western blot transfer.

Detection of IgM and IgG in cell lysates was made in Western blots,

*Corresponding author: Robert Bases, Department of Neuosurgery, Professor of Radiation Oncology, Albert Einstein College of Medicine, Montefiore Medical Center, 111 east 210th Street, Bronx NY 10467 USA, Tel: 914-380-2757; Fax 914632-3056; Email: rbases@verizon.net

Received August 31, 2018; Accepted September 14, 2018; Published September 19, 2018

Citation: Bases R, Lekhraj R (2018) lonizing Radiation and Lucanthone Enhance the IgG Content of Burkitt's Lymphoma Cells. J Bioanal Biomed 10:105-107. doi:10.4172/1948-593X.1000216

Copyright: @2018 Bases R, et al. This is an open-access article distributed under the terms of the Creative Commons Attribution License, which permits unrestricted use, distribution, and reproduction in any medium, provided the original author and source are credited. 


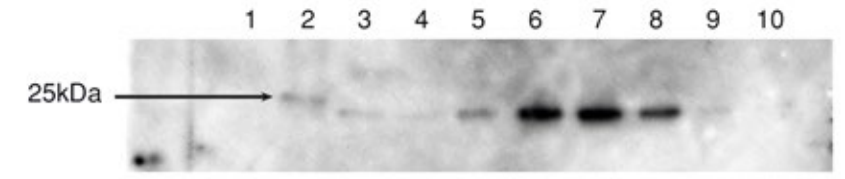

Figure 2A: Lucanthone treated CRL-1647 Burkitt's lymphoma cells contain more AID than untreated cells or the survivors of $5 \mathrm{~Gy}$. Lane 1: No cell lysates. Lane 2: AID $0.25 \mu \mathrm{g} 25 \mathrm{kDa}$. Lanes 3, 4, 5: Lysates from $1.4 \times 106$ untreated cells AID $0.26 \mu \mathrm{g}$. Lanes 6, 7, 8: Lysates from $3.3 \times 105$ cells $48 \mathrm{~h}$ after $8 \mu \mathrm{M}$ lucanthone AID $0.98 \mu \mathrm{g}$. Lanes 9, 10: Lysates from $1.5 \times 106$ cells 35 generations after $5 \mathrm{~Gy}$ AID $0.14 \mu \mathrm{g}$. Normalization of AID values by reference to cellular actin content (Figure 2B) indicated that the elevated AID obtained after lucanthone treatment were significant at $p \leq 0.024$. Radiation treatment did not increase cellular AID. Lane 2: $0.25 \mu \mathrm{g}$ of standard AID: 392 density units (arrow). Lanes 3, 4, 5: 251, 306,628 density units for lysates from untreated cells. Lanes 6, 7, 8: 1,982, 1,533, 969 density units for lysates from lucanthone treated cells. Lanes 9, 10: 338,99 density units for lysates from irradiated cells.

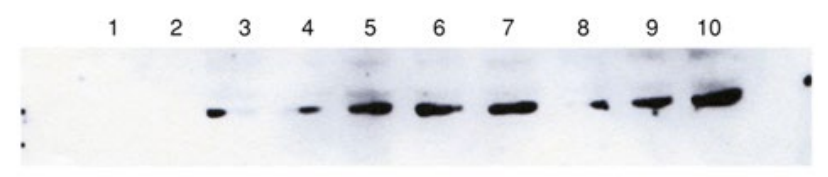

Figure 2B: Actin content of cell lysate fractions of Figure 2A. Antibodies were stripped from the nitrocellulose membrane of Figure $2 \mathrm{~A}$ and it was restained with mouse anti actin, followed by horseradish peroxidase goat anti-mouse antibodies. $42 \mathrm{kDa}$ bands are shown. Lane numbers correspond to lanes in Figure 2A. Lanes $3,4,5: 17,828 ; 23,664 ; 67,739$ density units, untreated cells. Lanes 6, 7, 8: 60,527; 62,402; 22, 814 density units, lucanthone treated cells. Lanes 9, 10: 55,084, 89216 density units, irradiated cells.

using goat anti human IgG precoupled to horseradish peroxidase (SC 2453) (Santa Cruz Biotechnology, Inc, Santa Cruz California, 95060).

This antibody reacts with IgM and more strongly with IgG. An advantage is that both IgG and IgM can be determined in the same cell lysate aliquot in the same gel lane. Quantitation is made by reference to immunodensities of reference standards in the gel. To characterize the relative abundance of $\operatorname{IgG}$ and $\operatorname{IgM}$ in an aliquot, relative immunodensities were determined: $\operatorname{IgG} /(\operatorname{IgG}+\operatorname{IgM})$. For untreated Burkitt lymphoma cells the ratio was $0.20 \pm 0.05$ SE. After transfer of immunoglobulins to nitrocellulose membranes and blocking with 5\% milk proteins, membranes were stained with antibody, rinsed, and immunofluorescence was induced with ECL reagent RPN2209 (GE Health Care, Amersham, Buckinghamshire. HP7 9NA, UK). After exposure to $\mathrm{x}$-ray film, gel band IgG and IgM were scored by densitometry. Complete transfer of proteins from gels to nitrocellulose membranes was verified by loading one lane of each gel with a mix of multicolored purified proteins encompassing the sizes of IgM and IgG (Kaleidoscope-BioRad). After transfer, bands were found in the membranes, none in the gels.

Actin was determined in cell lysates by electrophoresis in tris glycine minigels and transfer to nitrocellulose membranes. The actin bands were stained first with mouse anti actin (Cal Biochem mAb, JLA 20 CAT \#CP01) at 1:5000 dilution for 2 hours followed by goat anti mouse IgM precoupled to horse radish peroxidase (JA 1200) at 1:2000 dilution for 2 hours. Immunofluorescence then was induced by the ECL reagent and bands detected by exposure to X-ray film were scored by densitometry. Cell lysates had been prepared without mercaptoethanol, to prevent interference with IgM. Because of this, actin aggregates species were encountered in the gel lanes. Their sizes were from $\sim 10^{5}$ MW to $\sim 10^{6} \mathrm{MW}$. Therefore, the densities of all the actin reactive species in each lane were determined together.

- Human IgG 1 purified Ultraleaf Isotype CTRL was purchased from Biolegend, 9727 Pacific Heights Blvd, San Diego, CA 92121.

- Human IgM was purchased from Fisher Thermofisher.com.

- Horseradish peroxidase linked donkey anti human IgG was from Biolegend.

- AID was purchased from Enzymax, Lexington, KY 40503.

- Anti AID: Rat monoclonal antibody was purchased from Cell Signaling (AIDEK2569 - Item 4959S) 3 Trask Lane, Danvers, MA 01923.

- Goat anti rat IgG coupled to horseradish peroxidase was from Cell Signaling (Item 7077S)

- Irradiations of cells in growth medium were made in plastic flasks at $4 \mathrm{~Gy} /$ minute, $\mathrm{D}_{\max } 1.5 \mathrm{~cm}$, by a Varian linear accelerator.

\section{Results and Discussion}

Figure 1 shows increased IgG to IgM cell content ratios $22 \mathrm{~h}$ after 10 Gy and 4 days after 5 Gy. However, increased cellular AID was not found after radiation (Figures 2A). By contrast, increased cellular AID was significantly elevated $48 \mathrm{~h}$ after $8 \mu \mathrm{M}$ lucanthone (Figures $2 \mathrm{~A}$ and $2 \mathrm{~B})$ and the $\operatorname{IgG} /(\operatorname{IgG}+\operatorname{IgM})$ ratios were also elevated (Figure 1).

These results suggest two or more enzyme activities which elevate $\operatorname{IgG} /(\operatorname{IgM}+\operatorname{IgG})$. Lucanthone increased cellular AID content as well. Ionizing radiation induced the IgG increase with little or no participation by AID, suggesting a role for other enzyme activities. AID due to lucanthone may be supplementary to the radiation induced activity. Radiation might be inducing a more primitive APOBEC cytidine deaminase [2].

Lucanthone's action in inducing abasic cites in cell DNA [3] and DNA strand breaks [4] likely caused a different spectrum of strand break species than encountered after radiation. DNA nicks separated by 250 nucleotides on opposite strands can strongly mediate class switch recombination by AID [5]. Double strand break response factors influence end joining features of IgH class switch [6].

DNA strand species determinants of the AID response by lucanthone and APOBEC cytidine deaminases after radiation are as yet unknown.

Lucanthone was formerly used to safely treat schistosomiasis in hundreds of thousands of patients [7]. More recently, we found that lucanthone was a clinically useful adjuvant to radiation therapy in the treatment of brain metastases [8]. Patient serum levels of $8 \mu \mathrm{M}$, the concentration used in the present study, were maintained for several weeks without incident, when care was taken to avoid interference from other medications.

Roles for lucanthone and radiation in clinical macroglobulinemias are worth considering. Such treatment might restore enhanced levels of IgG, consistent with in vitro results described here.

\section{Author Contributions}

- Conception and design: Bases R.

- $\quad$ AID, IgG and IgM assays: Bases R and Lekhraj R. 
Citation: Bases R, Lekhraj R (2018) lonizing Radiation and Lucanthone Enhance the IgG Content of Burkitt's Lymphoma Cells. J Bioanal Biomed 10:105-107. doi:10.4172/1948-593X.1000216

\section{Grant Support}

This work was supported by the Rome Sisters Foundation for Cancer Research, by grants to R. Bases.

\section{References}

1. Bases R, Lekhraj R (2017) Enhanced content of IgG in Burkitt's lymphoma cells after treatment with the topoisomerase II injibitor, lucanthone. J Bioanal Biomed 9: 186-193.

2. Liu MC, Liao WY, Buckley KM, Yang SY, Rast JP, et al. (2018) AID/APOBEClike cytidine deaminases are ancient innate immune mediators in invertebrates. Nat Commun 9: 1948-1959.

3. Mendez F, Goldman JD, Bases RE (2002) Abasic sites in DNA of He La cells induced by lucanthone. Cancer Investigation 20: 983-991.

4. Bases R, Leifer A, Rozycki H, Blake C, Neubort S (1977) Effects of lucanthone on the sedimentation properties of DNA from He La Cells. Cancer Res 37: 2177-2181.

5. Ling AK, Socc Le MX, Chen AY, Hung L, Martin A (2018) Double stranded DNA break polarity skews repair pathway choice during intrachromosomal and interchromosomal recombination. Proc Natl Acad Sci USA 115: 2800-2805.

6. Panchakshari RA, Zhang X, Kumar V, Du Z, Wu P-C, et al. (2018) DNA double strand break response factors influence end-joining features of $\lg \mathrm{H}$ class switch and general translocation junctions. Proc Natl Acad Sci USA 115: 762-767.

7. Blair DM (1958) Lucanthone Hydrochloride: A Review. Bull World Health Organ 18: $989-1010$.

8. Del Rowe JD, Bello J, Mitnick R, Sood B, Fillippi C, et al. (1999) Accelerated regression of brain metastases in patients receiving whole brain radiation and the topoisomerase II inhibitor lucanthone. Int J Radiation Oncol Biol Phys 43 89-93. 